\title{
A new Nematoda (Thelastomatidae) parasite of Coleoptera larvae from Argentina
}

\author{
M. F. ACHINELLY ${ }^{1}$, N. B. CAMINO ${ }^{2}$ \\ ${ }^{1}$ Centro de Estudios Parasitológicos y de Vectores, CEPAVE, Calle 2 № 584, La Plata, Argentina; \\ ${ }^{2}$ Investigador CIC, E-mail: nemainst@cepave.edu.ar
}

\begin{abstract}
Summary
Leidynema saltense n. sp. (Nematoda, Thelastomatidae), a parasite of larvae of Cyclocephala modesta (Coleoptera, Scarabaeidae) from Salta province, Argentina, is described and illustrated. This species is characterised by the presence of an intestinal caecum in the female, and four pairs of genital papillae in the male, one pair of which is large, ventral and pre-anal and three pairs are subventral and postanal.
\end{abstract}

Key words: Leidynema saltense n. sp.; Thelastomatidae; parasite; Coleoptera; Scarabaeidae

\section{Introduction}

Thelastomatids (Nematoda: Thelastomatidae) live in the alimentary canal of a variety of insects. The study of this family revealed the presence of various species (Adamson and Van Waerebeke 1992). One of these genera is Leidynema, which was first described by Schwenk (in Travassos 1929), with L. appendiculatum (Leidy, 1850) as type species. This is characterized by having a gut diverticulum and by the arrangement of the genital papillae in the male, with four pairs of genital papillae, one large ventral pre-anal and three subventral and postanal (Adamson and Van Waerebeke 1992). At present, six species belonging to this genus have been reported: L. appendiculatum (Leidy 1850) Chitwood 1932, L. delatorrei Chitwood 1932, L. periplaneti Farooqui 1967, L. portentosae Van Waerebeke 1978, L. schwenkei Farooqui 1967, and L. socialis (Leidy, 1850) Adamson and Van Waerebeke 1992. In this contribution, we report, describe and illustrate another species Leidynema saltense n. sp., a parasite of larvae of Cyclocephala modesta Burmeister (Coleoptera: Scarabaeidae) from Salta, Argentina.

\section{Materials and methods}

Larvae of Cyclocephala modesta Burmeister, found in Salta $(\mathrm{n}=16)$, were collected by hand and then put in individual vials. In the laboratory, using Poinar's techniques (1975), the insects were kept at $5{ }^{\circ} \mathrm{C}$ for $10 \mathrm{~min}$, and then they were dissected in Petri dishes with distilled water under a binocular microscope. The nematodes were found in the intestine of the insects and killed in distilled water at $60{ }^{\circ} \mathrm{C}$ for $2 \mathrm{~min}$. They were then put in a solution of distilled water + TAF for $48 \mathrm{~h}(1: 1)$; finally, we finished fixation in pure TAF. Fixed specimens were employed for drawing and measurements using a camera lucida microscope, and a micrometer in a Zeiss compound microscope. Measurements for the holotype male and allotype female are given in micrometers, and the mean value followed by the standard deviation is given in parenthesis.

\section{Results}

Genus Leidynema Schwenk (in Travassos 1929)

Leidynema saltense n. sp. (Fig. $1 \mathrm{~A}-\mathrm{F}$ )

Diagnosis: Leidynema saltense $\mathrm{n}$. $\mathrm{sp}$. is identified by the presence of an intestinal caecum in the female (Fig. $1 \mathrm{~A}$ ), and four pairs of genital papillae in the male, of which one pair is large, ventral and pre-anal and the other three pairs are subventral and postanal (Fig. $1 \mathrm{E}, \mathrm{F})$.

Description: Cuticle striated throughout length of body in both sexes. Amphids small and pore-like. Mouth with eight labiopapillae. Stoma simple with thick walls (Fig.1 G). Oesophagus divided into two cylindrical parts of which posterior is longer than anterior, distinct isthmus, and a valvular basal bulb (Fig. $1 \mathrm{~A}, \mathrm{~B}$ ). Intestine with long caecum in females. Excretory pore at base of oesophagus. 

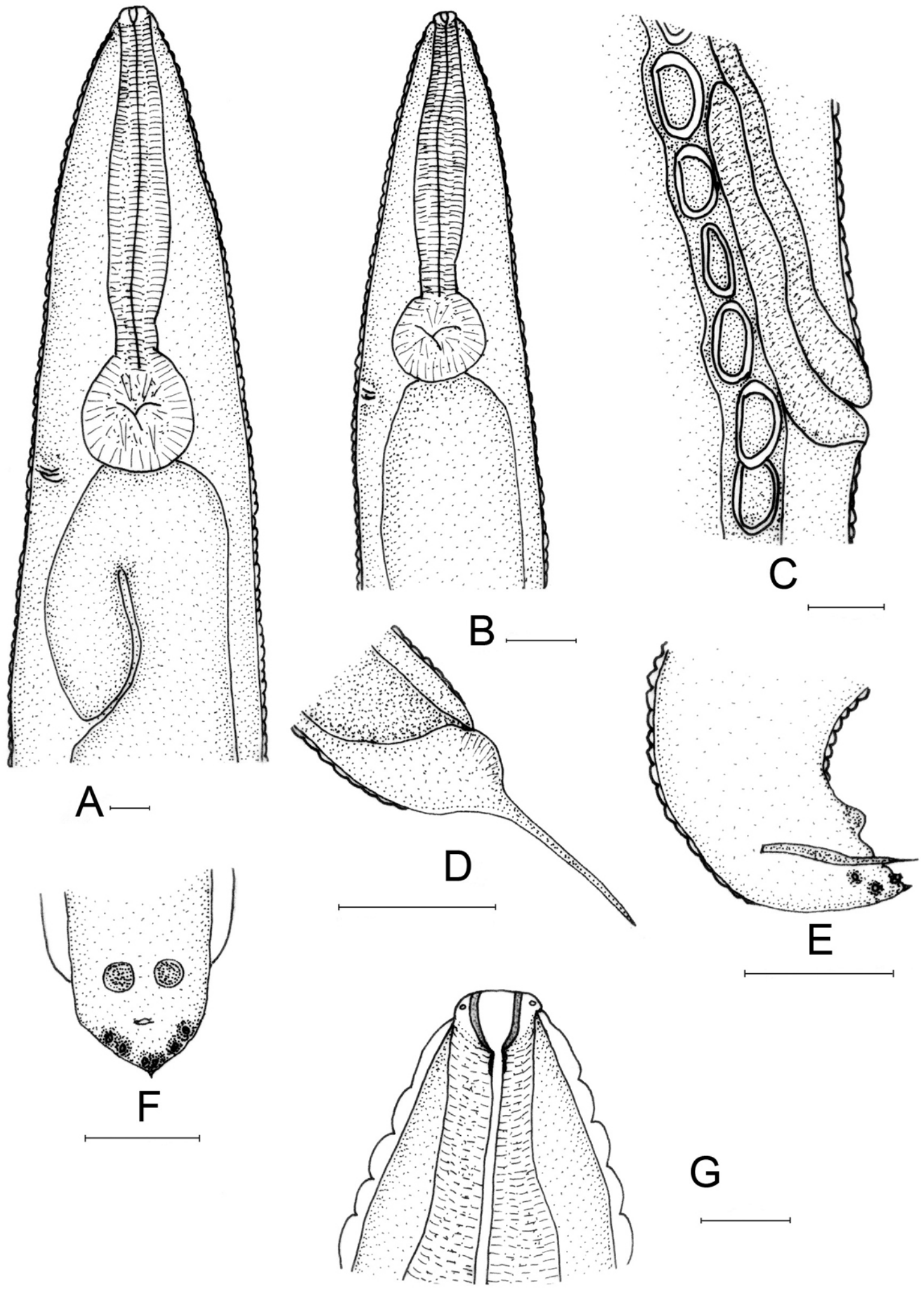

Fig. 1. Leidynema saltense n. sp. A. Anterior end of female, ventral view. B. Anterior end of male, ventral view. C. Vagina and uterus with eggs. D. Posterior end of female. E. Posterior end of male, lateral view. F. Posterior end of male, ventral view. G. Stoma region of the female. Bars $=50 \mu \mathrm{m}$. 
Vulva protruding near middle of body (Fig. 1 C). Vagina long. Eggs ellipsoidal, smooth shell without filaments. Female with a cuticular flap to protect the anus. Tail of female long and filiform (Fig. 1 D). Male with lateral alae all along the body (Fig. 1 F). Single spicule (Fig. 1 E). Four pairs of genital papillae, one large ventral pre-anal and three subventral and postanal; no tail appendage (Fig. $1 \mathrm{~F})$.

Male $(\mathrm{n}=9)$ : Total length: $656 \mu \mathrm{m}(642.87 \pm 86.06)$; diameter of labiopapillae: $22 \mu \mathrm{m}(21.95 \pm 1.63)$; oesophagus length: $190 \mu \mathrm{m}(188.39 \pm 31.72)$; distance from anterior end to excretory pore: $186 \mu \mathrm{m}(183.14 \pm 32.71)$; greatest width: $83 \mu \mathrm{m}(82.31 \pm 9.98)$; spicule length: $54 \mu \mathrm{m}(53.98$ $\pm 1.63)$; tail length: $60 \mu \mathrm{m}(59.98 \pm 1.63)$.

Female $(\mathrm{n}=18)$ : Total length: $3,990 \mu \mathrm{m}(3,199.41 \pm$ 712.58); diameter of labiopapillae: $39 \mu \mathrm{m}$ (41.89 \pm 3.56$)$; oesophagus length: $432 \mu \mathrm{m}(462.22 \pm 46.76)$; distance from anterior end to excretory pore: $460 \mu \mathrm{m}$ (452.2 \pm 39.44); greatest width: $325 \mu \mathrm{m}$ (315.02 \pm 79.84); vagina length: $284 \mu \mathrm{m}(304.08 \pm 58.88)$; vagina width: $46 \mu \mathrm{m}$ $(45.24 \pm 0.96) ; \mathrm{V}: 48.8 \%(48.74 \pm 0.96)$; length and width of eggs: $62 \mu \mathrm{m}(61.98 \pm 1.63)$ x $38 \mu \mathrm{m}(38.93 \pm 2.58)$.

Type host: Cyclocephala modesta Burmeister (Coleoptera: Scarabaeidae)

Type locality: Lesser, Salta, Argentina. Col. Camino, april $15^{\text {th }} 2000$.

Type material: deposited in the Helminthologica collection, $\mathrm{N}^{\circ}$ 4847, Museo de La Plata, Paseo del Bosque s/n, 1900 La Plata, Argentina.

Etymology: The name refers to the geographical site of collection.

\section{Discussion}

The genus Leidynema, with the type species L. appendiculatum (Leidy 1850) Chitwood 1932, is clearly defined as having a gut diverticulum. Leidynema saltense n. sp. is close to six species L. appendiculatum, L. delatorrei Chitwood 1932, L. periplaneti Farooqui, 1967, L. portentosae van Waerebeke, 1978, L. schwenki Farooqui, 1967, and L. socialis (Leidy, 1850), in the shape of the oesophagus and intestine, vulva near midbody, a single spicule, and the caudal extremity abruptly truncate with short terminal spine.

L. appendiculatum can be separated by the presence in the male of a pair of large subventral pre-anal, a pair of subventral postanal and a pair of small subdorsal papillae; the male has no lateral alae but the female has prominent lateral alae, the tail ends in a spine-like projection. L. delatorrei differs by having a pair of large laterovental pre-anal papillae, and postanal papillae: one pair just posterior to the anus, then two pairs, and a pair at the base of the tail appendage. L. periplaneti differs because the male lacks

RECEIVED MAY 4, 2007 lateral alae and has one pair of pre-anal, one pair of adanal and three pairs of postanal papillae. L. portentosae is distinguished because the male has three pairs of thick papillae: two pairs ventral grouped, and other pair reduced, ventral cuticular protuberances and the spicule long and thin. L. schwenki differs by having two pairs of pre-anal papillae and three pairs of postanal papillae. L. socialis can be characterized by the male having many postanal papillae, only a single central one, then two well developed pairs near the caudal appendage with many small papillae. Biswas and Chakravarty (1963) described another species, L. stylopygi, from India, but this is considered by Kloss (1966) and Farooqui (1967) as a synonym of L. appendiculatum.

Leidynema saltense $\mathrm{n}$. sp. is characterized mainly by the intestine with a caecum in female, and the male with four pairs of genital papillae as described above.

This is the first record of the genus Leydinema in Salta Province, Argentina.

\section{Acknowledgment}

This study was supported in part by the Comisión de Investigaciones Científicas de la Provincia de Buenos Aires (CIC) and Consejo Nacional de Investigaciones Científicas y Técnicas (Conicet), Argentina.

\section{References}

AdAmson, M. L., VAN WAEREBeKe, D. (1992): Revision of the Thelastomatoidea, Oxyurida of invertebrate host. I. Thelastomatidae. Syst. Parasitol., 21: $21-63$

Biswas, P. K., Chakvarty. G. K. (1963): The systematic studies of the zooparasitic nematodes. Z. Parasitenkd., 23: $411-428$

Chitwood, B. G. (1932): A synopsis of the nematodes parasitic in insects of the family Blattidae. Z. Parasitenkd., 5: $14-50$

FAROOQUI, M. N. (1967): On a known and some new species of insect nematodes. Zool. Anz., 178: 276 - 296

KLOSS, G. R. (1966): Revisao dos Nematoides de Blattaria do Brasil. Pap. Avulsos Zool. (Sao Paulo), 18: 147 - 188

LEIDY, J. (1850): Description of some nematoid entozoa infesting insects. Proc. Acad. Nat. Sci. Philadelphia, 5: $100-102$

POINAR G. O. JR. (1975): Entomogenous nematodes: A manual and host list of insect-nematode associations. E.J. Brill, Leiden, 317 pp.

Travassos, L. (1929): Contribuiçao preliminar á systematica dos nematoideos dos Artropodes. Mem. Inst. Oswaldo Cruz, 5: $19-25$

VAN WAEREBEKE, D. (1978): Description de Cephalobellus ovumglutinosus n. $\mathrm{sp}$. et de Leidynema portentosae n. sp. (Nematoda:Thelastomatidae), parasites intestinaux de blattes, et redéfinition du genre Leidynema Schwenk, 1926 (in Travassos, 1929): Rev. Nématologie, 1: 151 - 163 